\title{
ANALISIS PERAMALAN PENJUALAN PRODUK KERIPIK PISANG KEMASAN BUNGKUS (Studi Kasus : Home Industry Arwana Food Tembilahan)
}

\author{
Siti Wardah*), Iskandar \\ Jurusan Teknik Industri, Fakultas Teknik dan Ilmu Komputer, Universitas Islam Indragiri, Tembilahan
}

(Received: January 21, 2016 / Accepted: August 15, 2016)

\begin{abstract}
ABSTRAK
Peramalan adalah metode untuk memperkirakan suatu nilai dimasa depan dengan menggunakan data masa lalu. Penelitian ini dilakukan pada Home Industry Arwana Food. Pada penelitian ini, penulis membahas mengenai analisis peramalan penjualan produk kripik pisang untuk jenis kemasan bungkus. Peramalan yang dilakukan mengggunakan tiga metode yaitu metode Moving Average, metode Exponential Smoothing with Trend dan metode Trend Anayisis dengan membandingkan tingkat kesalahan (error) terkecil, maka metode peramalan yang terpilih yaitu metode Trend Analysis, dengan nilai MAD sebesar 161,3539, MSE sebesar 55744,16, dan standar error sebesar 242,947. Dari analisis pengolahan data yang telah dilakukan berdasarkan metode peramalan yang terpilih, peramalan penjualan terhadap produk kripik pisang jenis kemasan bungkus adalah sebanyak 1121,424 atau 1122 bungkus/bulan, artinya pihak Home Industry Arwana Food Tembilahan harus menyediakan produk kripik pisang kemasan bungkus adalah sebanyak 1122 bungkus untuk tiap bulannya.
\end{abstract}

Kata kunci : peramalan penjualan; kripik pisang; metode moving average; metode exponential smoothing with trend; metode trend analysis

\begin{abstract}
Forecasting is a method to estimate a value of the future using past data. This research was conducted at the Home Industry Arowana Food. In this study, the authors discuss the analysis of product sales forecasting banana chips for this type of packaging wrap. Forecasting that do use traditional three methods are methods Moving Average, Exponential Smoothing method with Trend and Trend Anayisis method by comparing the level of errors (error) the smallest, then the selected forecasting method is the method of Trend Analysis, with a value of 161.3539 MAD, MSE of 55744, 16, and the standard error of 242.947. From the analysis of data processing that has been carried out based on the method chosen forecasting, sales forecasting for products banana chips are as many types of packaging wrap 1121.424 or 1122 packs / month, meaning the Home Industry Arowana Food Tembilahan must provide products banana chips wrapped packs is as much as 1122 wrap for each month.
\end{abstract}

Keywords : sales forecasting, banana chips, methods moving average, exponential smoothing methods with trend, trend analysis method

\section{Pendahuluan}

Suatu perusahaan yang bergerak dalam bidang jasa penjualan atau pendistribusian produk, selalu menginginkan keberhasilan dalam aktifitasnya dimasa yang akan datang. Ini menunjukkan bahwa setiap perusahaan selalu berusaha untuk tetap dapat berkembang dalam bidang usahanya di masa depan.

\footnotetext{
${ }^{*}$ Penulis Korespondensi. email: sitiwardahst@yahoo.co.id
}

pimpinan yang memiliki kemampuan untuk dapat menetapkan keputusan yang tepat dalam menghadapi masa depan yang penuh ketidak pastian, agar perusahaan dapat meraih apa yang menjadi tujuannya. Salah satu hal yang paling penting untuk mewujudkan hal tersebut adalah memperkirakan atau meramal (forecasting) besarnya penjualan atau permintaan pelanggan akan barang atau jasa yang dihasilkan.

Seorang manejer selalu berkeinginan untuk dapat memperkirakan atau memprediksikan besarnya seluruh 
permintaan jangka pendek atau jangka panjang sekalipun untuk masing - masing produknya. Dalam kaitannya dengan penyusunan rencana penjualan, informasi yang diperoleh dari peramalan penjualan akan memberikan gambaran berguna tentang prospek permintaan produk tersebut di pasar. Baik atau tidaknya prospek penjualan suatu produk pada dasarnya tidak hanya berdasarkan kemampuan ataupun penggunaan metode peramalan yang tepat. Namun yang tidak kalah pentingnya adalah proses perencanaan produksi yang menentukan terhadap mutu atau kualitas produk, penilaian pasar yang menentukan jenis pasar, kebijakan promosi dan pemasaran yang menentukan cerahnya prospek produk kedepannya. Hal ini secara langsung ataupun tidak, akan berpengaruh terhadap manajemen persediaan perusahaan dan ini menunjukkan keterkaitan di antara faktor-faktor tersebut.

Hasil peramalan dalam prakteknya hampir tidak pernah secara mutlak tepat. Hal ini karena keadaan maupun kejadian di masa depan tidak menentu. Walaupun demikian, apabila semua faktor penting yang mempengaruhi telah diperhitungkan dan model hubungan dari faktor-faktor tersebut ditentukan dengan baik, maka hasil peramalan akan mendekati kondisi yang sebenarnya, maka harus dilakukan dengan hatihati terutama pemilihan metode untuk digunakan dalam suatu kasus tertentu. Hal ini dipertimbangkan kerena tidak ada satupun metode dari perkiraan atau peramalan yang dapat dipergunakan secara universal untuk seluruh keadaan atau situasi.

Hampir semua bagian perusahaan membutuhkan hasil ramalan penjualan. Hasil peramalan lingkungan bisnis dimana perusahaan beroperasi pada umumnya mempunyai implikasi pada ramalan penjualan. Karena itu peramalan penjualan dalam sebuah perusahaan sangat dibutuhkan tidak hanya untuk jangka pendek saja melainkan juga untuk jangka panjangnya.

Di Tembilahan, banyak perusahaan yang bergerak dalam bidang penjualan ataupun distribusi produkproduk kebutuhan sehari-hari untuk para pelanggan atau konsumen. Perusahaan-perusahaan ini tentunya mempuyai pangsa pasar tersendiri. Untuk dapat mempertahankan keberadaannya ataupun posisinya di pasar, maka perusahaan-perusahaan tersebut mempunyai strategi-strategi ataupun metode-metode yang diterapkan dalam rangka mengembangkan usahanya. Hal ini tentunya dapat dilakukan atau diterapkan apabila telah dilakukan survey ataupun melakukan peramalan untuk mewujudkan tujuan mereka baik di segi peramalan pasar, peramalan produksi, maupun peramalan penjualannya.

Home Industry Arwana Food adalah salah satu usaha yang bergerak dalam bidang industri produk makanan ringan. Industri ini berdiri pada tahun 1994 yang beralamat di Jalan Tanjung Harapan No. 15 Tembilahan. Permasalahan yang terjadi di Home Industry Arwana Food sering terjadi kekurangan persediaan produk makanan keripik pisang kemasan bungkus seperti pada Gambar 1 karena pada industri tersebut tidak melakukan peramalan sebelum melakukan produksi. Kondisi seperti ini dapat membuat industri kehilangan pelanggan dan turunya laba. Oleh sebab itu dibutuhkan suatu metode peramalan penjualan produk pada Home Industry Arwana Food untuk mengetahui berapa besar kebutuhan produk yang disediakan agar dapat memenuhi kebutuhan konsumen di tahun yang akan datang dan tidak terjadi kekosongan persediaan.

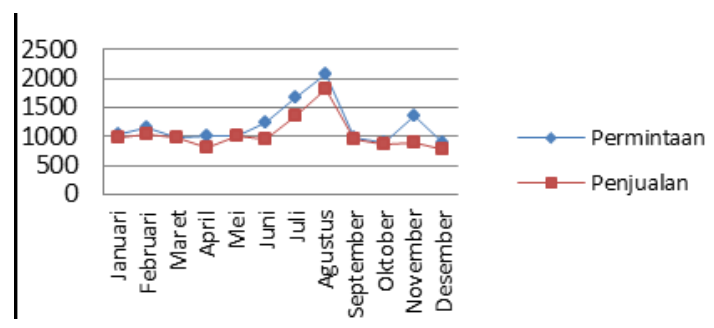

Gambar 1. Grafik Permintaan dan Penjualan Produk Pada Tahun 2012

\section{Tinjauan Pustaka \\ Peramalan}

Peramalan adalah metode untuk memperkirakan suatu nilai dimasa depan dengan menggunakan data masa lalu. Peramalan juga dapat diartikan sebagai seni dan ilmu untuk memperkirakan kejadian pada masa yang akan datang, sedangkan aktivitas peramalan merupakan suatu fungsi bisnis yang berusaha memperkirakan penjualan dan penggunaan suatu produk sehingga produk-produk itu dapat dibuat dalam kuantitas yang tepat (Gaspersz, 2002).

Peramalan yang dibuat selalu diupayakan agar dapat :

1. Meminimumkan pengaruh ketidak pastian terhadap perusahaan.

2. Peramalan bertujuan mendapatkan peramalan (forecast) yang bisa meminimumkan kesalahan meramal (forecast error) yang biasanya diukur dengan MSE(Mean Squared Error), MAE (Mean Absolute Error ), dan sebagainya (Subagyo, 1986). Peramalan yang baik adalah peramalan yang dilakukan dengan mengikuti langkah-langkah atau prosedur penyusunan yang baik yang akan menentukan kualitas atau mutu dari hasil peramalan yang disusun. Pada dasarnya ada 3 langkah peramalan yang penting, yaitu (Assauri,1984) :

1. Menganalisa data yang lalu, tahap ini berguna untuk pola yang terjadi pada masa lalu.

2. Menentukan data yang dipergunakan. Metode yang baik adalah metode yang memberikan hasil ramalan yang tidak jauh berbeda dengan kenyataan yang terjadi.

3. Memproyeksikan data yang lalu dengan menggunakan metode yang dipergunakan, dan mempertimbangkan adanya beberapa faktor perubahan(perubahan kebijakan-kebijakan yang mungkin terjadi, termasuk perubahan kebijakan pemerintah, perkembangan potensi masyarakat, 
perkembangan teknologi dan penemuan-penemuan baru).

Sedangkan prinsip-prinsip peramalan yang perlu dipertimbangkan adalah :

1. Peramalan melibatkan kesalahan (error), peramalan akan hanya mengurangi ketidakpastian tetapi tidak menghilangkannya.

2. Peramalan sebaiknya memakai tolak ukur kesalahan peramalan, pemakai harus tahu besar kesalahan, yang dapat dinyatakan dalam satuan unit atau persentase (probability) permintaan aktual akan jatuh dalam interval peramalan.

3. Peramalan famili produk lebih akurat dari pada peramalan produk individu (item).

4. Peramalan jangka pendek lebih akurat dari pada peramalan jangka panjang, karena peramalan jangka pendek, kondisi yang mempengaruhi permintaan cenderung tetap atau berubah lambat, sehingga peramalan jangka pendek lebih akurat.

5. Jika memungkinkan coba melakukan perhitungan permintaan dari pada meramalkan permintaan.

Adapun karakteristik peramalan yang baik adalah :

1. Accuracy

2. Low Rupiah Cost Of Sofware Purchase Or Development

3. Low Computer Time Requirements

4. Low Computer Storage Requirements

5. On-line Capabilities

\section{Metode Peramalan}

\section{Metode Moving Average}

Moving average merupakan metode yang paling sering digunakan dan paling standar. Moving average adalah suatu metode peramalan umum dan mudah untuk menggunakan alat-alat yang tersedia untuk analisis tekniks. Moving average menyediakan metode sederhana untuk pemulusan data masa lalu. Metode ini beguna untuk peramalan ketika tidak terjadi tren, gunakan estimasi berbeda untuk mempertimbangkanya. Hal ini disebut dengan "bergerak" karena sebgai data baru yang tersedia, data yang tertua tidak digunakan lagi (Makridakis dkk, 1999).

Tujuan utama dari penggunaaan rata-rata bergerak adalah untuk menghilangkan atau mengurangi acakan dalam deret waktu. Teknik rata-rata bergerak dalam deret waktu terdiri dari pengambilan suatu kumpulan nilai-nilai yang diobservasi, mendapatkan rata-rata dari nilai ini, dan kemudian menggunakan nilai rata-rata tersebut sebagai ramalan untuk periode yang akan datang (Assauri, 1984).

Peramalan dengan teknik moving average melakukan perhitungan terhadap nilai data yang paling baru sedangkan data yang tua/lama akan dihapus. Nilai rata-rata dihitung berdasarkan jumlah data, yang angka rata-rata bergeraknya ditentukan dari harga 1 sampai nilai $\mathrm{N}$ data yang dimiliki.

moving average dihitung dengan menggunakan rumus sebagai berikut :

Jurnal Teknik Industri, Vol. XI, No. 3, September 2016

$$
F_{t+1}=\frac{1}{N} \sum_{i=t-N+1}^{t} X_{i}
$$

Di mana $\mathrm{t}$ adalah nilai yang paling akhir dan $\mathrm{t}+1$ adalah priode berikutnya, untuk priode mana suatu ramalan dibuat.

$F_{t+1}=$ ramalan untuk priode berikut, $\mathrm{t}+1$

$\mathrm{X}_{\mathrm{t}, \mathrm{t}-1, \mathrm{t}-2}=$ nilai observasi/sebenarnya dari variabel itu pada priode $\mathrm{t}, \mathrm{t}-1, \mathrm{t}-2, \ldots$

$\mathrm{N}=$ jumlah observasi yang digunakan dalam menghitung rata-rata bergerak.

Dalam model moving average dapat dilihat bahwa bahwa semua data observasi memiliki bobot yang sama yang membentuk rata-ratanya. Padahal data observasi terbaru seharusnya memiliki bobot yang lebih besar dibandingkan dengan data observasi dimasa lalu. Hal ini dipandang sebagai kelemahan dalam metode moving average.

\section{Nilai Tengah}

Diberikan sekumpulan data yang meliputi $\mathrm{N}$ periode, waktu terakhir dan ditentukan $\mathrm{T}$ titik data pertama sebagai kelompok-kelompok inisialisasi dan sisanya sebagai kelompok pengujian.

Metode rata-rata sederhana adalah mengambil rata-rata dari semua data dalam kelompok inisialisasi tersebut

$$
\overline{\mathrm{X}}=\sum_{i=1}^{T} \mathrm{X}_{i} I T=F_{T+1}
$$

Sebagai ramalan untuk periode $(\mathrm{T}+1)$ kemudian bila mana data periode $(\mathrm{T}+1)$ tersedia, maka dimungkinkan untuk menghitung nilai kesalahannya.

$$
\mathrm{e}_{\mathrm{T}+1}=\mathrm{X}_{\mathrm{T}+1}-\mathrm{F}_{\mathrm{T}+1} \ldots \ldots \ldots \text {... (3) }
$$

Dalam kelompok data historis masa lalu terdapat satu lagi titik data sehingga, nilai rata-ratanya yang baru adalah :

$$
\overline{\mathrm{X}}=\sum_{i=1}^{T+1} \mathrm{X}_{i} I(T+1)=F_{T+2}
$$

Dan unsur galat yang baru, jika $\mathrm{X}_{\mathrm{T}+2}$ adalah

$$
\mathrm{e}_{\mathrm{T}+2}=\mathrm{X}_{\mathrm{T}+2}-\mathrm{F}_{\mathrm{T}+2} \ldots \ldots \ldots . .(5)
$$

\section{Rata-rata bergerak sederhana atau tunggal (Simple Moving Average)}

Salah satu cara untuk mengubah pengaruh masa lalu terhadap nilai tengah sebagai ramalan adalah dengan menentukan sejak awal berapa jumlah nilai pengamatan masa lalu yang akan dimasukkan untuk menghitung nilai tengah. Untuk menggambarkan prosedur ini digunakan istilah rata-rata bergerak karena setiap muncul pengamatan nilai yang baru, nilai ratarata yang baru dapat dihitung dengan membuang nilai observasi yang paling tua dan dimasukkan nilai pengamatan yang terbaru.

\section{Rata-rata bergerak berganda}

Untuk mengurangi galat sistematis yang terjadi bila rata-rata bergerak dipakai pada data berkecendrungan maka dikembangkan metode rata-rata bergerak linear. Dasar metode ini adalah menghitung 
rata-rata bergerak berganda, merupakan rata-rata bergerak dan menurut simbol dituliskan sebagai MA (M $\mathrm{x} \mathrm{N}$ ) dimana MA adalah $\mathrm{M}$ periode dari MA N-periode. Prosedur peramalan rata-rata bergerak meliputi tiga aspek :

1. Penggunaan rata-rata bergerak tunggal pada waktu $t$ $\left(\mathrm{s}_{\mathrm{t}}\right)$.

2. Penyesuaian yang merupakan perbedaan antara ratarata bergerak tunggal dan ganda pada waktu $\mathrm{t}\left(\mathrm{S}_{\mathrm{t}}{ }_{\mathrm{t}}\right.$ $\left.\mathrm{S}{ }_{\mathrm{t}}\right)$.

3. Penyesuaian untuk kecendrungan dari periode $t$ keperiode $\mathrm{t}+1$ (atau ke periode $\mathrm{t}+\mathrm{m}$ ).

Penyesuain dua paling efektif bila trend bersifat linear dan komponen galat acaknya tidak begitu kuat. Penyesuaian ini efektif karena adanya kenyataan bahwa MA tunggal tertinggal (lags) di belakang deret data yang menunjukkan trend.

Apabila deret data menunjukkan trend, maka MA tunggal akan menghasilkan sesuatu yang menyerupai galat sistimatis dan galat sistematis ini dapat dikurangi dengan menggunakan perbedaan antara nilai rata-rata bergerak tunggal dan nilai bergerak ganda.

Prosedur rata-rata bergerak linear secara umum dapat diterangkan melalui persamaan berikut :

$$
\begin{aligned}
& S_{t}^{\prime}=\frac{X_{t}+X_{t-1}+X_{t-2}+\ldots+X_{t-N+1}}{N} \\
& S_{t}^{\prime \prime}=\frac{S_{t}+S_{t-1}^{\prime}+S_{t-2}+\ldots+S_{t-N+1}^{\prime}}{N} \\
& \mathrm{a}_{\mathrm{t}}=\mathrm{S}_{\mathrm{t}+}\left(\mathrm{S}_{\mathrm{t}}-\mathrm{S}_{\mathrm{t}}{ }_{\mathrm{t}}\right)=2 \mathrm{~S}_{\mathrm{t}}{ }-\mathrm{S}^{\prime}{ }_{\mathrm{t}} \\
& b_{t}=\frac{2}{N-1}\left(S_{t}^{\prime}-S^{\prime \prime}{ }_{t}\right) \\
& \mathrm{F}_{\mathrm{t}+\mathrm{m}}=\mathrm{a}_{\mathrm{t}}+\mathrm{b}_{\mathrm{t}} \mathrm{m}
\end{aligned}
$$

\section{Metode Exponential Smoothing}

Metode exponential smoothing adalah metode yang menunjukkan pembobotan menurun secara eksponensial terhadap nilai pengamatan yang lebih lama. Terdapat satu atau lebih parameter penulisan yang ditentukan secara eksplisit, dan hasil pilihan ini menentukan bobot yang dikenakan pada nilai observasi. (Makridakis dkk, 1999).

Metode pemulusan eksponensial tunggal (Singel Exponensial Smooting/SES)minimal membutuhkan dua buah data untuk meramalkan nilai yang akan terjadi pada masa yang akan datang (Makridakis dkk, 1999).

Kasus yang paling sederhana dari pemulusan (smoothing) eksponensial tunggal (SES), dengan persamaan sebagai berikut :

Misalkan pengamatan yang lama $\mathrm{X}_{\mathrm{t}-\mathrm{N}}$ tidak tersedia sehingga harus digantikan dengan nilai pendekatan. Salah satu pengganti yang mungkin adalah nilai peramalan periode sebelumnya $\mathrm{F}_{\mathrm{t}}$.

Persamaan umum yang digunakan dalam menghitung peramalan dengan metode pemulusan eksponensial adalah : $\mathrm{F}_{\mathrm{t}+1}=\alpha X_{t}+(1-\alpha) F_{t} \ldots \ldots \ldots$...(11)

$$
=\mathrm{F}_{\mathrm{t}}+\alpha\left(X_{t}-F_{t}\right)
$$

Jurnal Teknik Industri, Vol. XI, No. 3, September 2016

$$
=\mathrm{F}_{\mathrm{t}}+\alpha\left(e_{t}\right)
$$

\section{Metode Trend Analisis}

Metode Memisahkan tiga komponen tiga komponen terpisah dari pola dasar yang cendrung mencirikan deret data ekonomi dan bisnis. Komponen tersebut adalah factor trend, siklus dan musiman.

Pencocokan suatu garis lurus terhadap data stationer (horizontal) dapat dilakukan dengan cara meminimumkan MSE menggunakan:

$$
\bar{X}=\frac{\sum_{i=1}^{n} X_{i}}{n}
$$

garis trend linear untuk data deret berkala :

$$
\mathrm{X}_{\mathrm{t}}=\mathrm{a}+\mathrm{bt}
$$

Nilai a dan $b$ yang meminimumkan MSE dapat diperoleh dengan menggunakan persamaan berikut :

$$
\begin{array}{r}
b=\frac{n \sum t X-\sum t \sum X}{n \sum t^{2}-\left(\sum t\right)^{2}} \\
a=\frac{\sum X}{n}-b \frac{\sum t}{n} \cdots
\end{array}
$$

Dimana :

$$
\begin{aligned}
& \mathrm{a}=\text { intersep } \\
& \mathrm{b}=\text { kemiringan (slope) }
\end{aligned}
$$

\section{Ukuran Hasil Peramalan}

Ukuran akurasi hasil pengukuran peramalan yang merupakan ukuran kesalahan tentang tingkat perbedaan antara hasil peramalan dengan permintaan yang sebenarnya terjadi, ada 4 ukuran yang biasa digunakan, yaitu :

1. Rata-rata deviasi mutlak (Mean Absolute Deviation = MAD)

MAD merupakan rata-rata kesalahan mutlak selama periode waktu tertentu tanpa memperhatikan apakah hasil peramalan lebih besar atau lebih kecil dibandingkan dengan faktanya. Secara sistematis, MAD dirumuskan sebagai berikut :

$$
M A D=\sum\left|\frac{A_{t}-F_{t}}{n}\right| \ldots \ldots \ldots .
$$

Dimana :

$\mathrm{A}_{\mathrm{t}}=$ Permintaan Aktual pada Periode- $\mathrm{t}$

$\mathrm{F}_{\mathrm{t}}=$ Peramalan permintaan (forecast) pada periode- $\mathrm{t}$

$\mathrm{n}=$ Jumlah periode peramalan yang terlibat

2. Rata-rata kuadrat kesalahan (Mean Square Error $=$ MSE)

MSE dihitung dengan menjumlahkan kuadrat semua kesalahan peramalan pada setiap periode dan membaginya dengan jumlah periode peramalan. Secara sistematis, MSE dirumuskan sebagai berikut:

Dimana :

$$
M S E=\sum \frac{\left(A_{t}-F_{t}\right)^{2}}{n}
$$

$\mathrm{A}_{\mathrm{t}}=$ Permintaan Aktual pada Periode- $\mathrm{t}$

$\mathrm{F}_{\mathrm{t}}=$ Peramalan permintaan (forecast) pada periode $-\mathrm{t}$

$\mathrm{n}=$ Jumlah periode peramalan yang terlibat

3. Rata-rata kesalahan peramalan (Mean Forecast Error $=$ MFE) 
MFE sangat efektif untuk mengetahui apakah suatu hasil peramalan selama periode waktu tertentu terlalu tinggi atau terlalu rendah. Bila hasil peramalan tidak bias, maka nilai MFE akan mendekati nol. MFE dihitung dengan menjumlahkan semua kesalahan peramalan selama periode peramalan dan membaginya dengan jumlah periode peramalan, secara sistematis, MFE dinyatakan sebagai berikut:

$$
M F E=\sum \frac{\left(A_{t}-F_{t}\right)}{n}
$$

Dimana :

$\mathrm{A}_{\mathrm{t}}=$ Permintaan aktual pada periode $-\mathrm{t}$

$\mathrm{F}_{\mathrm{t}}=$ Peramalan permintaan (forecast) pada periode- $\mathrm{t}$

$\mathrm{n}=$ Jumlah periode peramalan yang terlibat

4. Rata-rata persentase kesalahan absolut (Mean Absolute Persentage Error $=$ MAPE)

MAPE merupakan ukuran kesalahan relatif, MAPE biasanya lebih berarti bila dibandingkan dengan MAD karena MAPE menyatakan persentase kesalahan hasil peramalan terhadap permintaan aktual selama periode tertentu yang akan memberikan informasi persentase kesalahan terlalu tinggi atau terlalu rendah. Secara sistematis, MAPE dinyatakan sebagai berikut:

$$
\text { MAPE }=\left(\frac{100}{n}\right) \sum\left|A_{t}-\frac{F_{t}}{A_{t}}\right| \ldots \ldots \ldots . .(20)
$$

Dimana :

$\mathrm{A}_{\mathrm{t}}=$ Permintaan aktual pada periode $-\mathrm{t}$

$\mathrm{F}_{\mathrm{t}}=$ Peramalan permintaan (forecast) pada periode- $\mathrm{t}$

$\mathrm{n}=$ Jumlah periode peramalan yang terlibat

\section{Verifikasi dan Pengendalian Peramalan}

Langkah penting setelah peramalan dibuat adalah melakukan verifikasi peramalan sedemikian rupa sehingga hasil peramalan tersebut benar-benar mencerminkan dari data masa lalu dan sistem sebab akibat dari sistem tersebut. Sepanjang aktualitas peramalan tersebut dapat dipercaya, hasil peramalan akan terus digunakan, jika selama proses verifikasi tersebut mengalami keraguan validitas metode peramalan yang digunakan, maka harus mencari metode lain yang lebih cocok. Validitas tersebut harus ditentukan dengan uji statistik yang sesuai.

Setelah peramalan dibuat, selalu timbul keraguan mengenai kapan kita harus metode peramalan yang baru. Peramalan harus selalu dibandingkan dengan permintaan aktual secara teratur, maka pada suatu saat harus diambil tindakan revisi ramalan jika ditemukan adanya bukti perubahan pola permintaan yang menyakinkan selain sebab itu perubahan permintaan harus diketahui, maka penyesuaian metoda peramalan perlu dilakukan segera setelah perubahan pola permintaan diketahui.

Banyak alat yang dapat digunakan untuk memverifikasi peramalan dan mendeteksi perubahan sistem sebab akibat melatarbelakangi perubahan pola permintaan. Bentuk yang paling sederhana adalah peta Jurnal Teknik Industri, Vol. XI, No. 3, September 2016 kontrol peramalan yang mirip dengan peta kontrol kualitas. Peta kontrol peramalan ini dapat dibuat dengan kondisi data yang tersedia minim.

\section{Metodologi Penelitian}

Langkah-langkah yang dilakukan pada penelitian ini adalah sebagai berikut :

1. Pendahuluan

Sebelum melakukan penelitian, maka silakukan penelitian pendahuluan untuk mengetahui permasalahan yang ada pada Home Industry Arwana Food.

2. Pengumpulan Data

Tahap pengumpulan data pada penelitian ini menggunakan data primer dan data sekunder. Data sekunder merupakan data yang diperoleh langsung dari perusahaan yang berbentuk dokumen atau catatan perusahaan. Adapun data sekunder yang dibutuhkan dalam penelitian ini adalah sebagai berikut :

1. Data profil Home Industry Arwana Food, struktur organisasi, lokasi perusahaan, jumlah karyawan dan jadwal kerja karyawan.

2. Data penjualan keripik pisang kemasan bungkus selama 3 tahun.

3. Pengolahan Data

Setelah data diperoleh, maka langkah selanjutnya adalah mengolah data dengan menggunakan program aplikasi komputer yaitu software $Q M$ (Quantitative Methodes) for Windows 2.1.

Pengolahan data ini bertujuan agar data mentah yang diperoleh bisa dianalisa dan memudahkan mengambil kesimpulan atau menjawab permasalahan yang sedang diteliti dengan menggunakan metode moving average, exponential smoothing whit trend dan trend analysis.

4. Analisis

Analisa yang penulis lakukan bertujuan untuk mempelajari masalah-masalah yang ada dan mengambil kesimpulan dari hasil penelitian. Untuk keperluan tersebut penulis menggunakan metode kuantitaf yaitu dengan menggunakan rumus-rumus yang berhubungan dengan meteode-metode yang digunakan.

5. Kesimpulan

Dari hasil pengolahan data dan analisa, maka dapat ditarik kesimpulan yang dapat menjawab rumusan masalah.

\section{Hasil Dan Pembahasan \\ Data Penjualan}

Sebelum pengolahan data dilaksanakan, sebaiknya melakukan plot data terlebih dahulu. Karena dari plot data kita dapat mengetahui pola aliran data yang akan kita ramal sehingga memudahkan kita dalam melakukan peramalan. Berdasarkan plot data dari data penjulan aktual dapat disimpulkan bahwa data berdistribusi bersifat musiman. Hal ini berdasarkan plot data yang telah dilakukan cenderung turun-naik. 


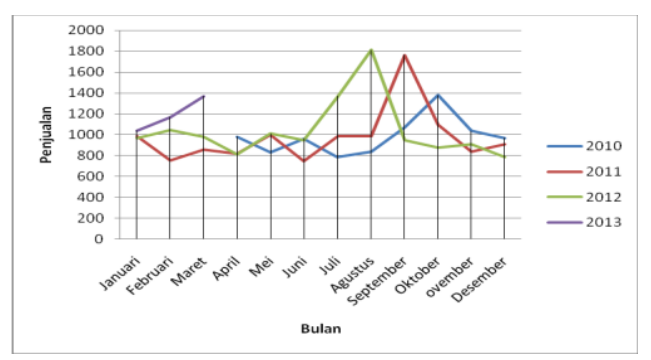

Gambar 2. Grafik Penjualan Produk Keripik Pisang Kemasan Bungkus

\section{Analisa Peramalan Setiap Metode \\ Metode Moving Average}

Untuk mendapatkan hasil peramalan yang lebih ekektif, maka kita menggunakan metode rata-rata bergerak sebanyak 2 periode, yaitu periode 1 dan periode ke 2 .

\section{Moving Average dengan Periode I}

Berdasarkan pada Tabel 1, didapat nilai forecast permintaan untuk periode berikutnya sebesar 1368 bungkus, nilai MAD sebesar 212,6286, MSE sebesar 86399,14 , dan Bias sebesar 12 sedangkan standart error sebesar 302,7135. Berdasarkan output tersebut maka dapat kita artikan bahwa tingkat kesalahan penggunaan metode ini sebesar 212,6286 untuk MAD dan 86399,14 untuk MSE.

Tabel 1. Forecasting Result Moving Average Periode I

\begin{tabular}{ll}
\hline Measure & Value \\
\hline Error Measures & \\
Bias (Mean Error) & 12 \\
MAD (Mean Absolute & 212,6286 \\
Deviation) & \\
MSE (Mean Squared Error) & 86399,14 \\
Standard Error & 302,7135 \\
Forecast next period & 1368 \\
\hline
\end{tabular}

\section{Moving Average dengan Periode II}

Berdasarkan Tabel 2, didapat nilai forecast penjualan untuk periode berikutnya sebesar 1269,5 bungkus, nilai MAD sebesar 219,7794, MSE sebesar 89357,98, dan Bias sebesar 18,8971 sedangkan standart error sebesar 308,128. Berdasarkan output tersebut maka dapat kita artikan bahwa tingkat kesalahan penggunaan metode ini sebesar 219,7794 untuk MAD dan 89357,98 untuk MSE. Namun untuk menentukan keputusan menggunakan metode ini atau tidak, maka kita akan membandingkan dengan metode lainnya.
Tabel 2.Forecasting Result Moving Average Periode 2

\begin{tabular}{lr}
\hline Measure & \multicolumn{1}{c}{ Value } \\
\hline Error Measures & \\
Bias (Mean Error) & 18,8971 \\
MAD (Mean Absolute & 219,7794 \\
Deviation) & 89357,98 \\
MSE (Mean Squared Error) & 308,128 \\
Standard Error & 1269,5 \\
Forecast next period & \\
\hline
\end{tabular}

Sebagai bahan perbandingan awal dapat kita bandingkan di antara kedua model rata-rata bergerak periode 1 dan 2. Dari pengolahan data didapat nilai MAD 1(212,6286) < MAD 2 (219,7794) dan nilai MSE $1(86399,14)<$ MSE $2(89357,98)$. Sehingga dapat disimpulkan untuk sementara bahwa model rata-rata bergerak periode 1 lebih baik dibandingkan periode 2 karena nilai MAD dan MSE perioe 1 lebih kecil dibandingkan periode 2 .

Di samping itu, jika kita lihat pola distribusi data peramalan periode ke pertama berbeda dengan periode kedua. Pola distribusi data peramalan penjualan periode ini mempunyai simpangan yang besar dari pada periode pertama.

Metode Exponential Smoothing With Trend $\alpha=0,5$ dan $\beta=0,5$

Dari output pada Tabel 3 didapat bahwa nilai forecast untuk periode berikutnya, yaitu sebesar 1321,469, nilai MAD sebesar 263,2664, nilai MSE sebesar 112759, dan Bias (Mean Error) sebesar 14,2113 dan Standart Error sebesar 345,8221. Berdasarkan output tersebut dapat kita artikan bahwa tingkat kesalahan peramalan penjualan sebesar 263,2664 untuk MAD dan 112759 untuk MSE.

Tabel 3. Forecasting Result Exponensial Smooting With Ternd $\alpha=0,5$ dan $\beta=0,5$

\begin{tabular}{lr}
\hline Measure & \multicolumn{1}{c}{ Value } \\
\hline Error Measures & \\
Bias (Mean Error) & 14,2113 \\
MAD (Mean Absolute & 263,2664 \\
Deviation) & 112759 \\
MSE (Mean Squared Error) & 345,8221 \\
Standard Error & 1321,469 \\
Forecast next period & \\
\hline
\end{tabular}




\section{Metode Trend Analysis}

Dari output Tabel 4 didapat bahwa nilai forecast untuk periode berikutnya, yaitu sebesar 1121,424 , nilai MAD sebesar 161,3539, nilai MSE sebesar 55744,16, Bias (Mean Error) sebesar 0 dan standart error $=$ 242,947. Berdasarkan output tersebut dapat kita artikan bahwa tingkat kesalahan peramalan sebesar 161,3539 untuk MAD dan 161,3539 untuk MSE.

Untuk pola ditribusi grafik peramalan terlihat bahwa metode ini mempunyai simpangan yang kecil dibandingkan dengan metode moving average dan exponential smoothing with trend.

Tabel 4. Forecasting Result Trend Analysis

\begin{tabular}{lrcc}
\hline \multicolumn{1}{c}{ Measure } & Value & $\begin{array}{r}\text { Future } \\
\text { Period }\end{array}$ & Forecast \\
\hline Error Measures & & 37 & 1121,424 \\
Bias (Mean Error) & 0 & 38 & 1127,086 \\
MAD (Mean & 161,3539 & 39 & 1132,749 \\
$\begin{array}{l}\text { Absolute Deviation) } \\
\text { MSE (Mean }\end{array}$ & 55744,16 & 40 & 1138,411 \\
$\begin{array}{l}\text { Squared Error) } \\
\text { Standard Error } \\
\text { (denom =n-2=34) }\end{array}$ & 242,947 & 41 & 1144,074 \\
Regression line & & 42 & 1149,736 \\
Peramalan(bungkus) & & 43 & 1155,399 \\
$=911,9096$ & & 44 & 1161,062 \\
+ 56625 * Time (x) & & 45 & 1166,724 \\
Statistics & & 46 & 1172,387 \\
Correlation & 0,2418 & & \\
coefficient & & 47 & 1178,049 \\
Coefficient of & & & \\
determination (r^2) & 0,0584 & 48 & 1183,712 \\
& & 48 & 1189,374 \\
\hline
\end{tabular}

\section{Analisa Metode Peramalan Terpilih}

Setelah ketiga metode peramalan digunakan, maka tahap selanjutnya adalah menentukan metode mana yang lebih efektif dan mempunyai tingkat kesalahan yang kecil tetapi mempunyai nilai peramalan yang besar.

Parameter yang digunakan untuk menentukan metode yang terbaik adalah melihat nilai MAD, MSE, standart error dan bias yang paling mendekati nol, Berdasarkan parameter tersebut, kita dapat menentukan metode yang terbaik dari beberapa metode yang ada untuk kasus peramalan penjualan dengan data yang bersifat musiman.

Untuk setiap metode pada penelitian ini terdapat variasi nilai MAD, MSE, Standart Error dan Bias sehingga untuk menentukan metode mana yang terbaik maka cara yang digunakan adalah memberikan pembobotan nilai pada faktor MAD, MSE, standart error dan bias. Setelah pemberian bobot nilai pada tiap faktor dilakukan, langkah selanjutnya adalah membandingkan kumulatif nilai pembobotan pada setiap metode peramalan penjualan tersebut.

Penilaian diberikan dengan memberikan nilai terkecil untuk setiap faktor penilaian pada setiap metode. Proses penilaian dilakukan dengan cara memberi nilai 1 dan seterusnya hingga 4 pada setiap metode dengan melihat satu faktor, yaitu nilai MAD, setelah nilai MAD dinilai barulah nilai MSE yang dilihat begitu juga dengan nilai Standart Error dan Bias. Sehingga dari proses pembobotan tersebut didapatkan hasil akhir pada setiap metode dan dapat dipilih metode mana yang mempunyai nilai yang paling kecil.

Berdasarkan analisa di atas dan pengolahan data pada Bab IV maka dapat kita bandingkan bahwa dari segi tingkat kesalahan, metode Trend Analysis mempunyai tingkat kesalahan yang lebih kecil dibandingkan metode yang lainnya, Nilai Biasnya adalah 0 maka metode yang terpilih dan yang sangat mendekati nilai nol adalah pada metode Trend Analysis ini.

\section{Analisa Penentuan Peramalan Jumlah Penjualan Produk Keripik Pisang Jenis Kemasan Bungkus}

Setelah dilakukan perhitungan peramalan, maka metode yang terpilih adalah metode peramalan trend analysis karena mempunyai tingkat kesalahan lebih kecil dibandingka dengan metode yang lain. Peramalan penjualan terhadap produk kripik pisang jenis kemasan bungus adalah sebanyak 1121,424 atau 1122 bungkus/bulan, artinya pihak Home Industry Arwana Food Tembilahan harus menyediakan produk kripik pisang untuk kemasan bungkus adalah sebanyak 1122 bungkus/bulan agar tidak mengalami kekurangan atau kelebihan persediaan produk kripik pisang untuk kemasan bungkus, dan dapat memenuhi semua permintaan konsumen terhadap penjualan kripik pisang kemasan bungkus sehingga bisa memperoleh keuntungan sesuai dengan yang diharapkan.

\section{Kesimpulan}

Untuk melakukan forcasting kita dapat menggunakan metode Moving Average, Exponential smoothing with trend dan Trend Analysis untuk mendapatkan nilai terkecil dari peramalan.

Berdasarkan pengumpulan dan pengolahan data serta analisa yang sudah dilakukan maka dapat kita bandingkan bahwa dari segi tingkat kesalahan serta perangkingan trend analysis mempunyai tingkat kesalahan yang lebih kecil dibandingkan dengan metode lainnya. Metode trend analysis mempunyai nilai MAD sebesar 161,3539, MSE sebesar 55744,16, dan standar error sebesar 242,947, maka dapat disimpulkan bahwa metode terpilih adalah metode Trend Analysis.

Berdasarkan analisa penetuan peramalan jumlah penjualan produk kripik pisang kemasan bungkus adalah sebanyak 1121,424 atau 1122 bungkus/bulan agar tidak mengalami kekurangan atau kelebihan persediaan produk kripik pisang untuk kemasan bungkus. 


\section{Daftar Pustaka}

Assauri, Sofyan. 1984. Teknik dan Metode Peramalan. Penerbit Fakultas Ekonomi Universitas Indonesia: Jakarta

Baroto, T. Perencanaan dan Pengendalian produksi. Jakarta: Ghalia Indonesia, 2002.

Makridakis, dkk. 1999. Metode dan Aplikasi Peramalan. Bina Rupa Aksara: Jakarta

Nasution A.H, dan Prasetyawan Y.P. Perencanaan dan Pengendalian Produksi. Edisi Pertama, Yogyakarta : Graha Ilmu, 2008.

Pujawan IN, Supply Chain Management. Surabaya: Penerbit Guna Widya, 2005.
Subagyo, Pangestu. 1986. Forcesting Konsep and Aplikasi. BPEE UGM: Yogyakarta

Surjasa D. Rancang Bangun Model Sistem Penunjang Keputusan Cerdas Untuk Sistem Rantai Pasokan Beras di Propinsi DKI Jakarta. Disertasi diterbitkan. Bogor : Institut Pertanian Bogor, 2011.

Tersine Ricard J. Principles Of Inventory and Materials Management. USA:Prentice Hall, Inc. 1994.

Vincent Gaspersz. 2002. Production Planing and Inventory Control. PT. Gramedia Pustaka Utama: Jakarta 